\title{
INDEPENDENCE OF BIDS IN PUBLIC PROCUREMENT ${ }^{1}$
}

\author{
Katarína Kalesná \\ Comenius University Bratislava, Faculty of Law
}

KALESNÁ, K. Independence of Bids in Public Procurement. Bratislava Law Review, Vol. 3, No. 2 (2019), pp. 69 - 75. ISSN 2585-7088, eISSN: 2644-6359

\begin{abstract}
The article compares the different approach of two bodies of economic regulation - EU competition law and public procurement law - to the concept of undertaking reflecting diverse goals both regulations follow. It starts with general characteristics of competition law and public procurement law, especially as far as their mutual relationship is concerned. In spite of many common goals and important intersections, there are also conflicting issues between them. And concept of undertaking is a topic where the point of view of both blocks of regulation differs. This diversity and its reasons are analysed on the background of the CJ EU judgement in case C-531/16.
\end{abstract}

Key words: undertaking, parent company, subsidiary, economic unit, competition, links between tenderers, independence of bids, EU competition law, public procurement law, EU law.

\section{INTRODUCTION}

European Union competition law and public procurement law are traditionally perceived as two separate economic regulations of the internal market. But gradual development of internal market as a principal goal of economic integration has shown that there are many interesting intersections between competition law and public procurement law. Many of them remain until now underexplored.

\section{COMPETITION LAW AND PUBLIC PROCUREMENT}

The importance of public procurement in the European Union has grown gradually depending on the whole development of the internal market. It is undoubted now, that public contracts have to comply with the principles of the Treaty on Functioning of the European Union („TFEU“) and first of all four freedoms of the internal market - free movement of goods, freedom of establishment and freedom to provide services and principles derived therefrom (equal treatment, non-discrimination, mutual recognition, proportionality and transparency). ${ }^{2}$ Therefore „public procurement has to be opened up to competition".

$1 \quad$ This article was supported by grant APVV-17-0641: Zefektívnenie právnej úpravy verejného obstarávania a jej aplikácie v kontexte práva Európskej únie.

2 Directive 2014/24/EU of the European Parliament and of the Council of 26 February 2014 on Public Procurement and Repealing Directive 2004/18/EC, recital, N.1.

3 Ibid. 
Competition belongs to the original main principles of the internal market functioning as the principal and decentralised self-regulator of the market due to the main economic functions it fulfils. Although traditionally treated separately, both public procurement and competition represent „sets of economic regulation directly related to the internal market... "4 safeguarding of the principle of an open market economy with free competition. ${ }^{5}$

Indeed, development of the internal market together with constant evolution in field of competition and public procurement ${ }^{6}$ have brought "clear trend of convergence between both sets of regulation".7 As, based on OECD data, expenditures on public contracts represent 10 - 15 percent of gross domestic product, public procurement market is an important part of the internal market, it is necessary, also in opinion of European Court of Justice („ECJ“) „to develop effective competition in the field of public contracts. ${ }^{\text {"8 }}$

Having in mind one of the principal goals of public procurement, „to determine... which tender is the most economically advantageous "9, as far as "price-quality ratio ${ }^{\text {"10 }}$ is concerned, it is quite clear, that „effectiveness of public procurement... is conditional upon the existence of competition..." ${ }^{11}$ and the framework of the public procurement has to be found in the competitive markets. ${ }^{12}$ Thus, the aim is to establish ,a market like mechanism "13 in public procurement and to simulate competitive constraint in those relations, where goods, works or services are purchased by public sector. ${ }^{14}$

In the intersection of both branches of economic law the attention was drawn until now mostly on collusion of the participants of public procurement process artificially replacing competition between/among them and thus denying the sense of the whole public procurement. Equally important in those cases is sanctioning of the tender cartels comprising not only fines for the restrictive behaviour but also a risk of exclusion of offenders from another procurement process.

Although it is very important to detect potential anticompetitive behaviour taking form of collusive tendering or bid rigging, the potential of mutual relationship of both corpuses of economic regulation is, of course, greater and many aspects covered by this intersection stay until now underexplored and underdeveloped, both in theory and practice. ${ }^{15}$ Both pieces of economic integration share undoubtedly common goals and principles and they rely on common economic theories ${ }^{16}$, but on the other hand there are also cases where the interests of public procurement

4 SÁNCHEZ GRAELLS, A. Public Procurement and the EU Competition Rules, (2nd) Edition. Oxford: Hart Publishing, 2015, p. 3.

5 Art. 119 (1) TFEU, Protocol on Internal Market and Competition.

6 SÁNCHEZ GRAELLS, A. Public Procurement and the EU Competition Rules. op. cit., p. 5.

7 Ibid.

8 Case C - 138/08 Hochtief and Linde- Kca-Dresden [2009] ECR I 988947 with referencies in Case C- 27/98 Francesco and Leitschutz [1999] ECR I - 5697 26; Joined Cases C-285/99 and C- 286/99 Lombardini and Mantovani [2001] ECR I-9233 34; Case C-470/99 Universale Bau [2002 ECR I-11617 89; and Case C-247/02 Sintesi[2004] ECR I-921535. (In ibid. p. 6).

9 Directive 2014/24/EU...recital, N.90

10 Ibid.

11 SÁNCHEZ GRAELLS, A. Public Procurement and the EU Competition Rules. op. cit., p. 11.

12 Ibid.

13 Ibid., p. 12.

14 KALESNÁ, K. Tendrové kartely a ich špecifiká. In POVAŽANOVÁ, K. Aktuálne otázky sútažného práva v Európskej únii a na Slovensku. Bratislava: UK, Právnická fakulta, 2015, pp.23 - 39, p. 23 and literature there cited.

15 SÁNCHEZ GRAELLS, A. Public Procurement and the EU Competition Rules. op. cit., p. 7, 9.

16 Ibid., p. 5 
and competition law might be different. This is why ,it is probably not an exaggeration to consider both competition law and public procurement law as substantially independent branches within EU economic law. ${ }^{\text {"17 }}$

\section{CONCEPT OF UNDERTAKING IN EU COMPETITION LAW}

One of the questions with a different point of view of public procurement and competition law can be concept of undertaking in both pieces of economic regulation.

From the competition law perspective there is no legal definition of the concept of undertaking. In order to achieve the widest possible application of the EU competition rules ,the word undertaking has been interpreted in the widest possible sense to include any legal or natural person engaged in some form of economic or commercial activity, whether in the provision of goods or services, including cultural or sporting activities..., banking..., insurance... and transport. ${ }^{118}$

ECJ has offered in its case law a definition of undertaking as a „unit carrying on an economic activity regardless its legal form and way of financing. " ${ }^{19}$ Undertaking thus represents economic unit „comprising uniform organisation of personal, material and immaterial means following an economic objective on lasting basis and participating on abusive behaviour under Art. 81 TEC." ${ }^{20}$ This notion of undertaking applies to undertakings in the public as well as the private sphere ${ }^{21}$, to individual undertakings, corporations or even whole economic units comprising the parent company and its subsidiary acting on the market as a single economic unit, although legally independent. ${ }^{22}$ That means that notion of an "economic unit" is not necessarily linked in the EU with a single natu-

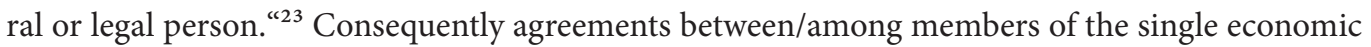
unit are not caught by Art. 101 TFEU. On the other hand, in participation of the economic unit on cartel behaviour, it is usually a parent company who is considered to be liable for infringement of the competition rules. This applies to company who is 100 percent owner of the subsidiary or who has executed a decisive influence on performance of a subsidiary. ${ }^{24}$

\section{ECONOMIC OPERATORS IN PUBLIC PROCUREMENT LAW}

As already mentioned, goals of public procurement and EU competition law may differ and it may evoke conflicting situations. This is particularly apparent as far as subjects of both blocks of legal regulation are concerned. Whereas EU competition rules are addressed to undertakings understood

\footnotetext{
Ibid., p. 3.

STEINER,J., WOODS, L.: EU Law. Oxford University Press, 2009, p. 666.

ECJ judgement C-41/90 Klaus Höffner and Fritz Elser v. Macroton GmbH, SbSD 1992, I-1979.

Judgement T-11/89 Shell, SbSD 1992, II-757.

STEINER, J., WOODS, L.: EU Law, op. cit., p. 667.

22 KALESNÁ, K. Je podnik (stále) legislatívnou výzvou? AFI, Universitatis Comenianae, Tomus XXXVI, 2/2017, p. 127.

23 BLAŽO, O.: Twenty Years of Harmonisation and Still Divergent: Development of Slovak Competition Law. Yearbook of Antitrust and Regulatory Studies. Vol. 20147 (9), University of Warsaw, Faculty of Management Press, p. 115.

24 PETR, M. Přičítání odpovědnosti za porušení soutěžního práva. In ANTITRUST 3/2013, p. 81.
} 
as whole economic units ${ }^{25}$ comprising different companies, e. g. parent company and its subsidiaries, public procurement law works in principle with single persons. ${ }^{26}$

\subsection{Judgement of the Court of 17 May 2018 in Case C-531/16}

\subsubsection{Facts of the case}

This different approach of the EU competition law and public procurement law was confirmed in the recent ECJ judgement of 17 May 2018 in case C-531/16. The dispute in the main proceedings concerned a public call for tenders for the provision of services relating to the collection of communal waste of the municipal authority of Šiauliai and its transportation to the place of treatment announced by the centre for waste management for this region on 9 July 2015. Four tenderers submitted tenders: Specializuotas transportas UAB (tenderer B), Ekonovus UAB, Specialus autotransportas UAB (tenderer A) and the group of operators VSA Vilnius and Švarinta UAB. Tenderers A and B are subsidiaries of Ecoservice UAB, which holds $100 \%$ and 98,2\% respectively of the shares of those undertakings. The Boards of Directors of tenderers A and B are made up of the same persons. ${ }^{27}$

There was not an obligation to disclose links with other operators participating in the same tendering procedure under national legislation. In spite of that tenderer B submitted a declaration of its autonomous and independent participation in the tendering procedure and requested all other operators to be treated as competitors. The contract was awarded to tenderer B. VSA Vilnius complained, that offers where not properly evaluated and the principles of equal treatment and transparency had been infringed. In its opinion tenderers $\mathrm{A}$ and $\mathrm{B}$ had acted as an association of undertakings. ${ }^{28}$

After the rejection of complaint by the contracting authority VSA Vilnius brought an action before Regional Court, Šiauliai, Lithuania, that annulled the decisions of the contracting authority. Court of Appeal, Lithuania, confirmed that judgement. According to their opinion, tenderers A and $B$ had to determine what was the influence of that link on the competition between them and they should have disclosed their links to the contracting authority. The declaration of the tenderer B was considered insufficient. In those circumstances The Supreme Court, Lithuania, decided to stay the proceedings and to request the preliminary ruling of the ECJ. ${ }^{29}$

\subsubsection{Preliminary ruling of the ECJ}

Several questions were submitted to the Court for preliminary ruling, first of all, whether related tenderers which submit separate tenders are in all cases obliged to disclose that relationship to the

25 E. g. Blažo compares notion of undertaking in Slovak and EU competition law: „Unlike European competition law, the Slovak competition act contains a definition of the notion of an „undertaking " for the purposes of application of national competition rules. Under Article 3(2) APEC the term ,undertaking“ means an entrepreneur pursuant to Article 2 of the Commercial Code, as well as natural and legal persons, their associations, and associations of these associaciations, with respect to their activities and conduct that is or may be, related to competition, regardless of whether or not these activities or conduct is profit oriented. The Commercial Code recognises four types of entrepreneurs: a) a person recorded in the Commercial Register; b) a person engaged in business activity under a trade licence; c) a person engaged in business activity under specialised legislation, e.g. lawyers, auditors, pharmacists, human and veterinary physicians; d) a person engaged in agricultural production as a „sole farmer" and registered in a particular register." (BLAŽO, O. Twenty Yars of Harmonisation and Still Divergent: Development of Slovak Competition Law, op. cit., p. 114).

Published by Wolters Kluwer SR in cooperation with Comenius University in Bratislava, Faculty of Law, Slovak Republic, ISSN (print): 2585-7088; ISSN (online): 2644-6359 
contracting authority. It is equally important to establish how the contracting authority has to proceed being aware of the existence of important links between certain tenderers. ${ }^{30}$

To answer the questions, the ECJ came to the conclusion that in absence of „express legislative provision or specific condition in the call for tenders or in the tender specifications governing the conditions for the award of a public contract, related tenderers submitting separate offers in the same procedure are not obliged to disclose, on their own initiative, the links between them to the contracting authority. ${ }^{\text {(31 }}$ The ECJ derived this conclusion from several facts of the case and relevant legal regulation. In its opinion, Directive 2004/18 does not prohibit related undertakings to submit offers in public procurement procedure. As it is desirable to ensure widest possible participation in the tendering procedure, it would not be effective to exclude systematically related undertakings from the same public procurement procedure. ${ }^{32}$ The ECJ pointed out that "groups of undertakings can have different forms and objectives, which do not necessary preclude controlled undertakings from enjoying a certain autonomy in the conduct of their commercial policy and their economic activities, inter alia, in the area of their participation in the award of public contracts. ${ }^{\text {"33 }}$

The ECJ has rejected the application of Article 101 TFEU, that does not apply in case of agreements or practices carried out by undertakings which constitute an economic unit. ${ }^{34}$

Concerning duties of the contracting authority, the ECJ stated, that the contracting authority „is obliged to verify, requesting, where appropriate, additional information from those tenderers, whether their offers are in fact autonomous and independent. If the offers prove not to be autonomous and independent, Article 2 of Directive 2004/18 precludes the award of the contract to the tenderers having submitted those tenders. ${ }^{\text {"35 }}$

\subsection{Opinion of Advocate General Campos Sánchez-Bordona}

Opinion of the Advocate General was in substance consistent with the judgement of the Court. According to him under conditions mentioned in the case, „related tenderers which submit separate tenders are not under a duty to disclose their links to the contracting authority ${ }^{\text {" } 36}$ and the contracting authority has ,to guarantee equal treatment of tenderers and the transparency of the procedure ${ }^{\text {“ }}{ }^{37}$ First of all, the contracting authority has to be in charge of undistorted competition between the tenderers. ${ }^{38}$ But in his words, ,in the area of tendering procedures, the aim is not so much to protect (general) competition between independent operators in the internal market as to protect (more specific) competition which must operate in procedures for the award of public contracts. From that perspective, what really matters is the separateness of and genuine difference between the respective tenders... whether the tenderers are independent or related economic operators. " 39

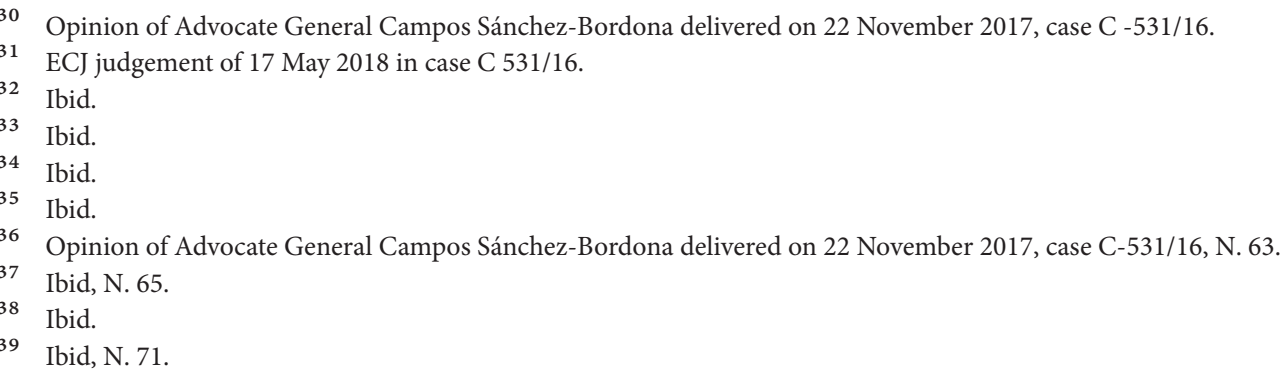


This opinion of the Advocate General deserves attention because it can be understood as making difference between (general) competition between independent operators in the internal market and (more specific) competition operating in procedures for the award of public contracts. In relation to that it should be stressed that there should not be a difference between competition principle generally in the internal market and specifically in public procurement procedures because ,article 101 (1) TFEU requires parallel competition between undertakings not only when they respond to a call for tenders, but generally in any market situation. " ${ }^{40}$ Similarly, ,the abuse of a dominant position will be proscribed and prosecuted exactly under the same circumstances in the public procurement arena as in any other type of market. ${ }^{\text {"41 }}$ So, it is competition as an institution ${ }^{42}$ to be protected by means of public procurement law, because ,the competition principle embedded in the EU public procurement directives is no more and no less than a particularisation, or specific enunciation of the more general principle of competition in EU law. “43

Obviously, there is a difference between competition law and public procurement law as far as addresses of the both legal regulations are concerned and in comparison with the notion of undertaking in competition law understood as a whole economic unit, the public procurement law including Directive N. 2014/24/EU defines tenderers as economic operators, in meaning of natural or legal persons and associations thereof. ${ }^{44}$ As already mentioned, the situation of more bids coming from one economic unit is not caught by Article 101 TFEU, so there is no bid rigging in this case. ${ }^{45}$

\section{CONCLUSION}

To summarize conclusions derived from ECJ judgement it is to stress that fact that the bidders in public procurement procedure belong to the same economic unit does not prevent them in presenting separate bids, if these bids are really independent. On the contrary, coordination of bids should lead to exclusion from the bidding procedure. ${ }^{46}$

The approach of public procurement law, resembling more the concept of undertaking in the Slovak than EU competition law, is in favour of possible widest choice among presented bids and selection of a bid that is fully in harmony with the public interest. As there is no general obligation of the bidders to inform the public authority about links between/among them, the authority is fully liable for the correctness to the whole procedure.

Concerning the opinion of Advocate General it is to underline that competition principle in public procurement law has to be understood as a special expression of the general competition principle in the EU law.

\footnotetext{
SÁNCHEZ GRAELLS, A. Public Procurement and the EU Competition Rules. op. cit., p. 203. 


\section{Bibliography:}

BLAZO, O. Twenty Years of Harmonisation and Still Divergent: Development of Slovak Competition Law. Yearbook of Antitrust and Regulatory Studies, Vol. 2014, 7 (9). Centre for Antitrust and Regulatory Studies (CARS), University of Warsaw, Faculty of Management, p. 109 - 123.

KALESNÁ, K. Tendrové kartely a ich špecifiká. In POVAŽANOVÁ, K. Aktuálne otázky sútažného práva v Európskej únii a na Slovensku. Bratislava: UK Právnická fakulta, 2015, p. 23 - 29.

KALESNÁ, K. Je podnik (stále) legislatívnou výzvou? In AFI, Universitas Comenianae, Tomus XXXVI, 2/2017, p. $122-133$.

PETR, M. Přičítání odpovědnosti za porušení soutěžního práva. In ANTITRUST 3/2013.

PETR, M. „Obrácený“ bid rigging - více nabídek z jedné ekonomické jednotky. In ANTITRUST 2/2018, p. 38 - 41.

SÁNCHEZ- GRAELLS, A. Public Procurement and EU Competition Rules. (2 ed.). Oxford: Hart Publishing, 2015.

STEINER, J., WOODS, L. EU Law. 10 ${ }^{\text {th }}$ Edition. Oxford University Press, 2009.

\section{Contact information:}

doc. JUDr. Katarína Kalesná, CSc.

e-mail: katarina.kalesna@flaw.uniba.sk

Comenius University Bratislava, Faculty of Law

Šafárikovo nám. 6

81000 Bratislava 1

Slovakia 